\title{
LARGE SCALE PRODUCTION OF HAPLOID PLANTS BY UNPOLLINATED OVULES CULTURE IN SQUASH (Cucurbita
} pepo, L.)

\author{
Badawi, \\ M. A. \\ E.I. Metwally*; Sahar \\ S. Taha* and \\ Marwa O. Arafeh* \\ * Department of Vegetable Crops , Faculty of Agric., Cairo Univ. , Egypt \\ ** Department of Vegetable Crops , Faculty of Agric., Tanta Univ. , Egypt
}

\begin{abstract}
Production of haploid plants using techniques such as anthers and ovule culture has long been considered important for genetic studies and plant breeders. These haploid plants can be used to produce homozygous dihaploid plants useful for plant breeding. This study is concerned with the production of dihaploid plants of Cucurbita pepo L. from ovule culture technique, gynogenic plants of squash were successfully produced by in vitro culture from unpollinated ovules at one day before anthesis. The ovules were placed on two media induction. Two temperature procedures were compared: 1 ) cold pre-treatment at $4^{\circ} \mathrm{C}$ for $0,8,16$ days of all three genotypes. The highest number of plantlets per 100 ovules was obtained from Rosina (22.5) ovules cultured on MS medium supplemented with $1.0 \mathrm{mg} / \mathrm{l} 2,4-\mathrm{D}$ and $1.0 \mathrm{mg} / \mathrm{l}$ Kin without cold treatment. While Eskandarani cv. gave the highest number of embryogenic callus on MS medium supplemented with $5.0 \mathrm{mg} / \mathrm{l} 2,4-\mathrm{D}$ at 8 days . 2) Cold $\left(4^{\circ} \mathrm{C}\right)$ and heat $\left(3^{\circ} \mathrm{C}\right)$ shocks post-treatment of Eskandarani $\mathrm{cv}$. for $0,4,8,16$ days. The highest number of plantlets per 100 ovules (17.0) was obtained from ovules cultured on MS medium supplemented with $5.0 \mathrm{mg} / \mathrm{l} 2,4-\mathrm{D}$ at $35^{\circ} \mathrm{C}$ for 16 days, On the other hand, the highest number of embryogenic callus (100.0) was obtained from ovules cultured on MS medium supplemented with $5.0 \mathrm{mg} / \mathrm{l} 2,4-\mathrm{D}$ at 4 days for $35^{\circ} \mathrm{C}$. Plantlets were acclimatized in the controlled environment. In each genotype, the root tips of plantlets were cytologically examined for ploidy level.

The derived plants are classified to $64 \%$ haploid and $36 \%$ diploid. Therefore, the ovule culture could be used as efficient method for haploid production in squash.
\end{abstract}

\section{INTRODUCTION}

Summer squash, (Cucurbita pepo L.) is a member of the Cucurbitaceae family and is considered one of the most popular vegetable crops in Arabian countries, pure lines are often considered a first step in genetic improvement of vegetable crops. This pure line are genetically pure or homozygous plants resulting from continuous self-fertilization for several generation, this takes more than seven years to produce such pure lines. The utilization of biotechnology and new in vitro culture techniques is necessary to reduce the number of years needed to obtain pure lines. One of the most successful methods to obtain such pure lines is anther or ovule culture techniques which considerably speed up the production of haploids for plant breeding programs. Successful production of haploid plants depends on a number of factors, especially the genotype, media composition, donor plant growing conditions and the age of ovules (number of days post-pollination) at culture. Therefore, the goal of this work was to study some factors affecting the production of squash haploid plants by ovule culture to achieve the pure 


\section{Badawi, M. A. et al.}

lines which are used as promising materials for breeders or as good productive genotypes for commercial cultivars and for $\mathrm{F}_{1}$ seed production

\section{MATERIALS AND METHODS}

This investigation was carried out in the Tissue Culture Laboratory, Vegetable Crops Department, Faculty of Agriculture, Cairo University, Giza, Egypt, as well as in the Tissue Culture Laboratory, Horticulture Department, Faculty of Agriculture, Kafr El-Sheikh, Tanta University, during the period from 2004 to 2006.

\section{II-1- The first experiment}

This experiment was carried out to study the effect of three cultivars of Squash; i.e. , Eskandarani , Gabbla , Rosina $F_{1}$ by temperature pre-treatment at $4^{\circ} \mathrm{C}$ for 0,8 , and 16 days on two media and their interaction on induction of haploid plants through unfertilized ovule culture.

\section{Plant materials and pre-treatment procedures:}

According to Metwally (1998) squash ovaries of three cultivars (Eskandarani ,Gabbla ,Rosina ) were harvested one day before anthesis and were exposed to cold temperature at $4^{\circ} \mathrm{C}$ for $0,8,16$ days (Fig. 1 ). After that, petals and style were removed. Then, the obtained ovaries were sterilized by soaking in $70 \%$ ethanol for two minutes, and rinsed three times with sterile distilled water, all this sterilization procedures occur inside the culture cabinet laminar air flow hood, then ovaries were placed on a sterilized paper towel to absorb the excessive surface water.

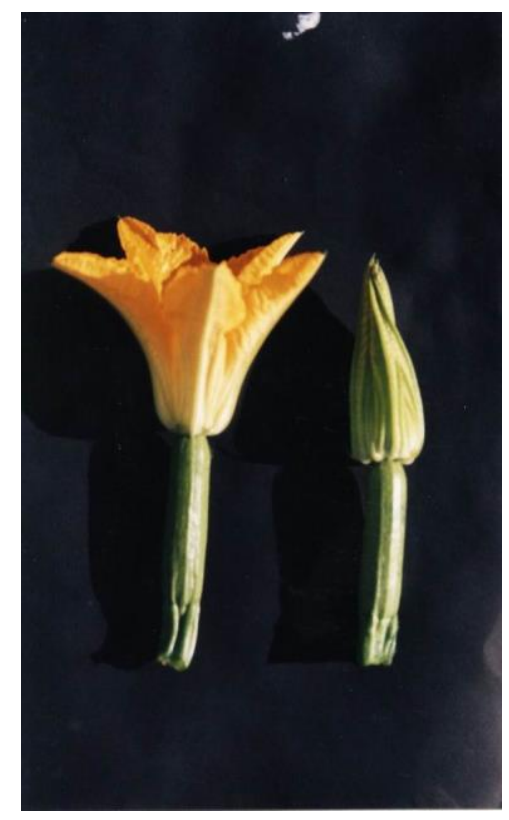

Fig. 1. ovary one day before anthesis. 


\section{Media composition and culture conditions:}

Two different induction media were used to produce haploid plants from three cultivars through ovule culture technique. These media were MS basal medium supplemented with one of the following combinations of plant growth regulators:

1- MS medium $+5.0 \mathrm{mg} / \mathrm{l} 2$, 4-D.

2- $\mathrm{MS}$ medium +1.0 mg/l 2, 4-D +1.0 mg/l Kin.

The $\mathrm{pH}$ was adjusted to 5.8 and solidified with $8.0 \mathrm{~g} / \mathrm{l}$ Agar and supplied with $30 \mathrm{~g} / \mathrm{l}$ sucrose before autoclaving. The medium of each treatment was distributed into Petri dishes. Each one containing $30 \mathrm{ml}$ medium under aseptic conditions. The ovules were excised from ovaries under cabinet laminar flow hood, 100 ovules were placed on each Petri dish. Then the dishes were sealed with parafilm and incubated at $25{ }^{\circ} \mathrm{C} \pm 1$ under $16 \mathrm{~h}$ photoperiod for four weeks (Fig. 2).

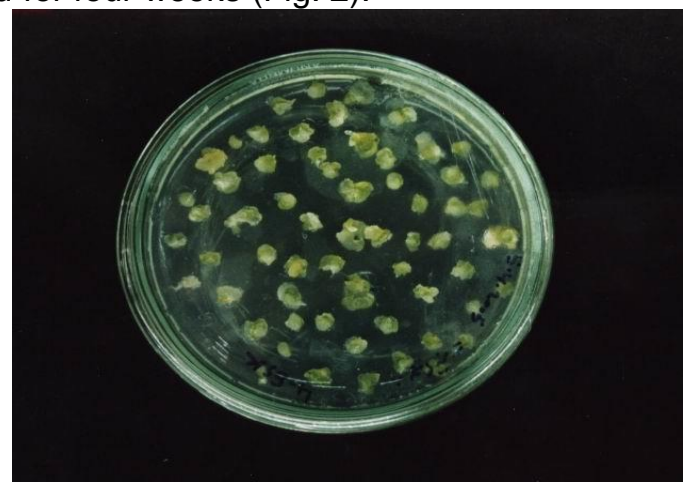

Fig. 2. Ovule at excision time.

Then ovules were transferred to hormone free MS medium for four weeks (Fig. 3, 4), the following data were recorded:

1 - Number of direct plantlets per 100 cultured ovules.

2- Number of unresponsed ovules per 100 cultured ovules.

3- Number of ovules that turn to callus.

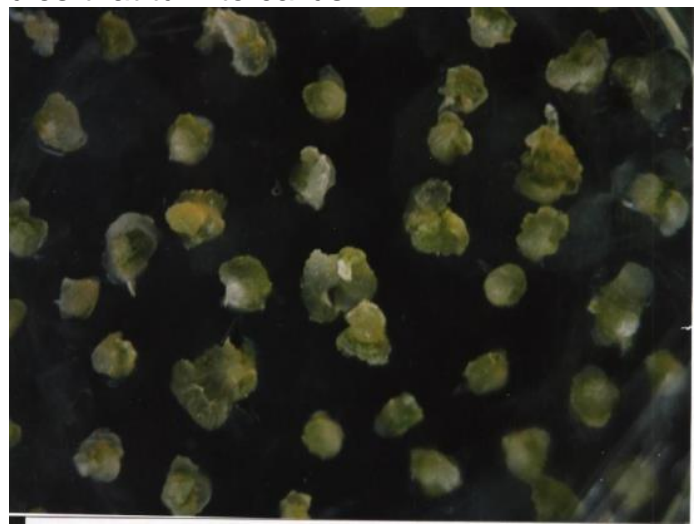

Fig. 3. Ovules $\overline{4}$ weeks after culture. 


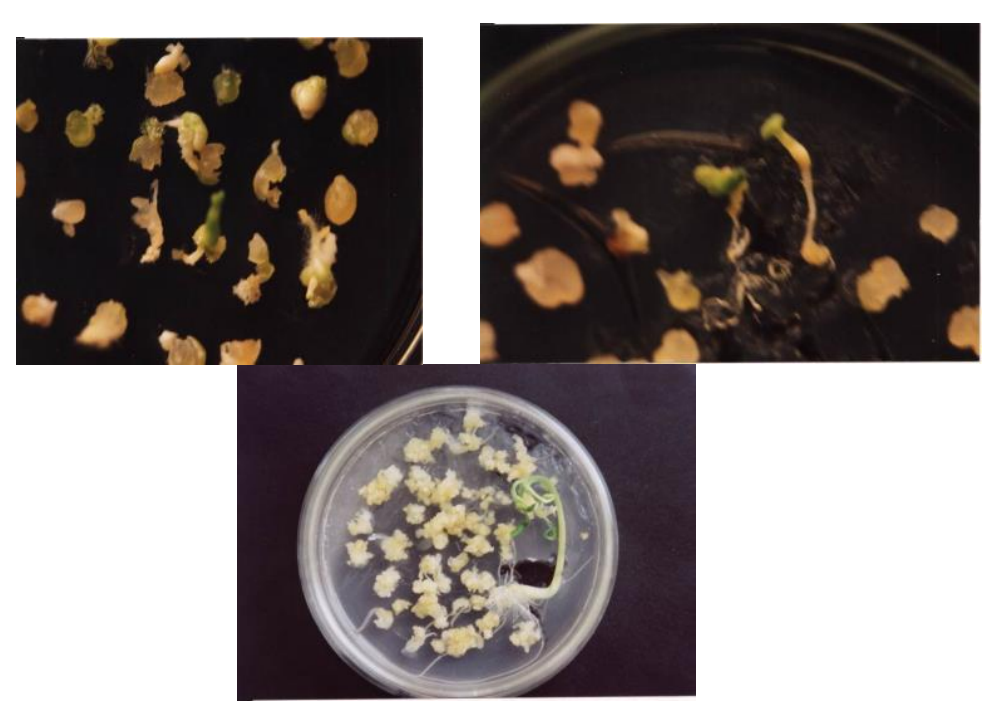

Fig. 4. Regenerated plantlets from ovule culture on free hormone after 4 weeks

\section{II-2-The second experiment:}

This experiment was carried out to study the effect of the heat and cold shocks as post-treatment after ovules culture, which are known as heat or cold pre-incubation on two different media by using Eskandarani summer squash cultivar.

\section{Media preparation and culture condition:}

The two media previously described at the first experiment were distributed into Petri dishes, and 100 ovules of Eskandarani cv. were cultivated on each Petri dish containing $30 \mathrm{ml}$ media. The Petri dishes were sealed with parafilm and exposed to low and high treatment temperature.

\section{Post-treatment temperature:}

Cultured ovules were exposed to cold shock at $4^{\circ} \mathrm{C}$ for $0,4,8$ and 16 days and heat shock at $35^{\circ} \mathrm{C}$ for $0,4,8$ and 16 days before incubation ,due to the fact that temperature shocks tend to improve gynogenesis.

After post-treatment temperature plates with ovules were incubated at $25 \stackrel{\circ}{ } \mathrm{C} \pm 1$ under $16 \mathrm{~h}$ photoperiod for four weeks. After that the ovules were transferred to hormone free MS medium and incubated under the same conditions for four weeks. Then the following data were recorded:

1 - Number of direct plantlets per 100 cultured ovules.

2- Number of unresponsed ovules per 100 cultured ovules.

3- Number of ovules turn to callus.

\section{III- PLANTS ADAPTATION:}

After obtaining plantlets they were transplanted individually into jars containing MS medium without hormones, and kept in 16h photoperiod (3000 lux) for four weeks. plantlets produced long and rolled root systems. Root system was cut off and plantlets were transferred into jars containing $50 \mathrm{ml}$ of strength hormone free MS medium supplemented with $1 \mathrm{~g} / \mathrm{l}$ pure sodium 
chloride and kept in $16 \mathrm{~h}$ photoperiod (3000 lux) for 10 days until a good root system was established ( 2 or 3 roots at $1-2 \mathrm{~cm}$ in length). (Fig 5 ).

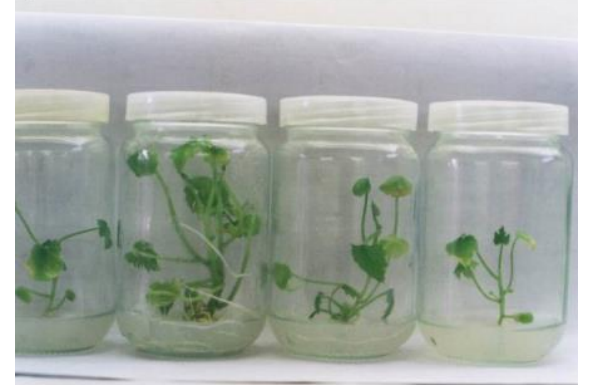

Fig. 5. Plantlets with storage root system after 4 weeks.

After that, the plants were washed under tap water and cultured in autoclaved sterilized pots containing peat moss and covered with clear plastic bags (Fig. 6) in order to maintain its humidity and were placed in the greenhouse for one week. Then, they were plated in the soil (Fig. 7).

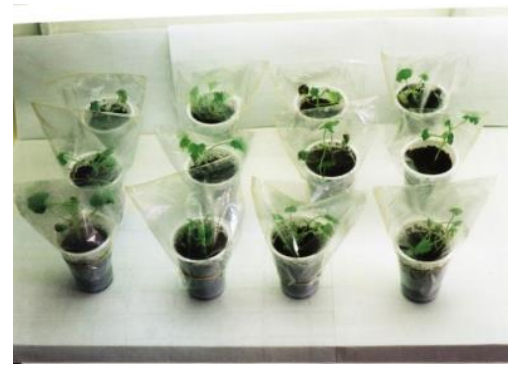

Fig. 6. regenerated plants in a pot covered with plastic bag.

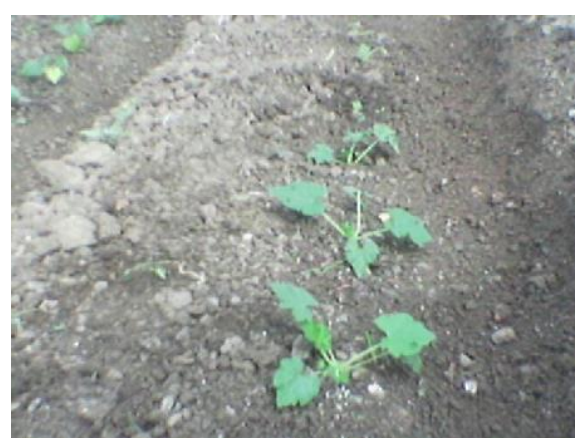

Fig 7. transferred plants to soil.

For cytological study, root tips of plants were cut off at approximately 2-3 cm length. After that, root tips were placed in colchicine solution $0.05 \%$ $\mathrm{w} / \mathrm{v}$ for three hours and they were washed with distilled water. They were fixed in 3:1 ethanol: glacial acetic acid for 24 hours at room temperature then washed with distilled water. Finally, these washed root tips were stored in 70 
$\%$ ethanol and kept in the refrigerator until being examined. Root slides examined with light microscope for chromosome counts after being stained with acetocarmine.

\section{RESULTS AND DISCUSSION}

\section{II-1-First experiment:}

\section{II-1-1- Effect of cultivars:}

Genotype proved to be one of the most important factors affecting gynogenesis in squash. Effect of cultivars on the production of embryos is presented in Table 1. The results show that variable responses were expressed by each of the three cultivars tested. The highest number of direct plantlets per 100 cultured ovules was achieved in ovules from Rosina cv. (7.375), while Gabbla cv. gave 5.625 plantlets per 100 ovules. On the other hand. Eskandarani cv. gave the lowest response (2.292 plantlets per 100 ovules).

Table 1: Effect of cultivars on ovule culture and plantlets regeneration from squash plants.

\begin{tabular}{|c|c|c|c|}
\hline Cultivar & $\begin{array}{c}\text { No. of direct } \\
\text { plantlets / } 100 \text { ovule }\end{array}$ & $\begin{array}{c}\text { No. of unresponsed } \\
\text { ovule / } 100 \text { ovule }\end{array}$ & $\begin{array}{c}\text { No. of ovules turn to } \\
\text { callus /100 ovule }\end{array}$ \\
\hline Gabbla & 5.625 b & 37.500 b & 56.000 b \\
\hline Eskandarani & 2.292 c & 33.167 c & 64.500 a \\
\hline Rosina F1 & 7.375 a & 45.667 a & 46.833 c \\
\hline F. test & ${ }^{\star \star}$ & ${ }^{\star \star}$ & ${ }^{\star \star}$ \\
\hline
\end{tabular}

** Indicate highly significant differences at $\mathrm{p}<0.01$ according to $\mathrm{F}$ test .

Means followed by a common letter are not significantly different at the $5 \%$ level according to Duncan 's test

Early work indicated that in unpollinated ovule embryogenesis occurs in the embryo sac cells especially in the egg cells which were able to divide and give embryos or callus (Pallares, 1984).

Data in Table 1 show that cultivars significantly affected ovules which turn into embryogenic callus. The highest number of ovules which produced embryogenic callus resulted from Eskandarani cv. (64.500 calli per 100 ovules). Gabbla cv. gave 56.000 calli per 100 cultured ovules, while the lowest number of ovules that turned into callus were obtained from Rosina cv. 46.833. Data in Table 1 show that cultivars were highly significant for the number of unresponded ovules, the highest number of unresponded ovules per 100 ovules was obtained from Rosina cv. 45.667, while Gabbla cv. gave 37.500 and the lowest number of unresponded ovules was 33.167 from Eskandarani cv.

A difference in response among genotypes was demonstrated. These results support previous reports of the effect of genotype on ovule culture in Cucurbitaceae. Vaulx and Chambonnet (1986) reported in squash that plants from 8 heterozygous $F_{1}$ cultivars differed in their response to ovule culture. Shail and Robinson (1987); Kwack and Fujieda (1988) suggested that induction of plantlets from Cucurbita pepo L. and Cucurbita moschata 
ovule culture depend on cultivars. It also supports reports of the important role of genotype on gynogenesis in other species. Hanna (1994) found that Texas Grano $1025 \mathrm{cv}$. produced more regenerated plantlets (1.224) than did Texas Grano $1015 \mathrm{cv}$. (1.1050)

II-1-2- Effect of media composition:

Growth regulators in ovary and ovule culture media was reported to be an essential and critical factor for optimal regeneration of haploid plants and may vary with species.

By using two media, data in Table 2 show that there were highly significant differences between the two media upon the number of direct plantlets and the number of unresponded ovules per 100 cultured ovules, and the number of ovules that turned to embryogenic callus.

MS media supplemented with $1.0 \mathrm{mg} / \mathrm{l} 2,4-\mathrm{D}$ and $1.0 \mathrm{mg} / \mathrm{l} \mathrm{Kin} \mathrm{gave} \mathrm{the}$ highest number of plantlets per 100 cultured ovules (7.361), while the media supplemented with $5.0 \mathrm{mg} / \mathrm{l}$ 2,4-D gave the lowest number of plantlets per 100 cultured ovules (2.833). The media supplemented with $5.0 \mathrm{mg} / \mathrm{l}$ 2,4-D gave the highest number of unresponded cultures ovules (44.306), while the media supplemented with $1.0 \mathrm{mg} / \mathrm{l}$ 2,4-D and $1.0 \mathrm{mg} / \mathrm{K} \mathrm{Kin}$ produced the lowest one (33.250).

Data in Table 2 also show that the medium supplemented with 1.0 $\mathrm{mg} / \mathrm{l}$ 2,4-D and $1.0 \mathrm{mg} / \mathrm{l} \mathrm{Kin} \mathrm{gave} \mathrm{the} \mathrm{highest} \mathrm{number} \mathrm{of} \mathrm{ovules} \mathrm{that} \mathrm{turned} \mathrm{to}$ callus per 100 ovules (59.111), while the other medium which was supplemented with $5.0 \mathrm{mg} / \mathrm{l}$ 2,4-D gave the lowest one (52.444). These results indicated that plant growth regulators are important for embryogenesis, and this correspond with the results obtained by Kwack and Fujieda (1988) on Cucurbita moschata. Vaulx and Chambonnet (1986) also indicated that the best medium for squash ovule culture is MS medium supplemented with 2,4-D and Kin at a concentration that ranged from 0.01 to $1.0 \mathrm{mg} / \mathrm{l}$. Metwally et al. (1998) reported that the best medium for gynogenesis was MS medium supplemented with $1.0 \mathrm{mg} / \mathrm{l} 2,4-\mathrm{D}$ and $1.0 \mathrm{mg} / \mathrm{l}$ Kin.

Table 2: Effect of media on ovule culture and plantlets regeneration from squash plants.

\begin{tabular}{|cr|c|c|c|}
\hline $\begin{array}{c}\text { Medium } \\
2,4-D\end{array}$ Kin & $\begin{array}{c}\text { No. of direct } \\
\text { plantlets / } 100 \\
\text { ovule }\end{array}$ & $\begin{array}{c}\text { No. of unresponsed } \\
\text { ovules / } 100 \text { ovule }\end{array}$ & $\begin{array}{c}\text { No. of ovules turn } \\
\text { to callus /100 } \\
\text { ovule }\end{array}$ \\
\hline 5.0 & 0.0 & 2.833 b & 44.306 a & 52.444 b \\
\hline 1.0 & 1.0 & 7.361 a & 33.250 b & 59.111 a \\
\hline F. test & $* \star$ & $* \star$ & $* \star$ \\
\hline
\end{tabular}

$\star \star$ Indicate highly significant differences at $\mathrm{p}<0.01$ according to $\mathrm{F}$ test .

Means followed by a common letter are not significantly different at the $5 \%$ level according to Duncan 's test.

\section{II-1-3- Effect of temperature pre-treatment:}

The effect of cold pre-treatment of various durations was investigated in this experiment. Data presented in Table 3 show that ovules from flower buds without pre-treatment produced a better embryogenic response than which were treated with $4^{\circ} \mathrm{C}$ for 8 and 16 days. The highest number of 
plantlets per 100 cultured ovules resulted from ovaries without cold pretreatment (7.250), while the lowest one was from ovaries treated with $4^{\circ} \mathrm{C}$ for 8 and 16 days (4.708 and 3.33),respectively. The differences between the highest number and the lowest one were statistically significant.

The high number of unresponded ovules per 100 cultured ovules was at 16 days cold pre-treatment (54.500), while the lowest one was at 8 days cold pre-treatment (29.583). On the other hand, 8 days cold pretreatment gave the highest number of ovules that turned to callus per 100 cultured ovules (65.250), while the lowest one was at 16 days cold pre-treatment (42.125).

Table 3: Effect of temperature pre-treatment on ovule culture and plantlets regeneration from squash plants.

\begin{tabular}{|c|c|c|c|}
\hline $\begin{array}{l}\text { Cold pre- } \\
\text { treatment(day) }\end{array}$ & $\begin{array}{c}\text { No. of direct } \\
\text { plantlets / } 100 \text { ovule }\end{array}$ & $\begin{array}{c}\text { No. of unresponsed } \\
\text { ovule / } 100 \text { ovule }\end{array}$ & $\begin{array}{c}\text { No. of ovules turn to } \\
\text { callus /100 ovule }\end{array}$ \\
\hline 0 & $7.250 \mathrm{a}$ & $32.250 \mathrm{~b}$ & $59.958 \mathrm{~b}$ \\
\hline 8 & 4.708 & $29.583 \mathrm{C}$ & 65.250 a \\
\hline 16 & 3.333 & 54.500 & $42.125 \mathrm{C}$ \\
\hline F. test & $\star \star$ & $\star \star$ & $\star \star$ \\
\hline
\end{tabular}

${ }^{\star \star}$ Indicate highly significant differences at $p<0.01$ according to $F$ test .

Means followed by a common letter are not significantly different at the $5 \%$ level according to Duncan 's test.

These different responses to cold pre-treatment have a positive effect on the development of embryos in some species. Similar results have been reported by Kwack and Fujieda (1988) for some Cucurbita ovaries which treated with cold pre-treatments and the best one was at $5^{\circ} \mathrm{C}$ for 2 days. Also, Lux et al. (1990) found that cold- pretreatment of sugar beet flower buds at $4^{\circ} \mathrm{C}$ lead to increase embryos yield at 4-5 days. Hanna (1994) reported an enhancing effect for cold pre-treatment at $4^{\circ} \mathrm{C}$ for 4 days in onion. While Metwally et al. (1998) reported that the highest embryogenic ovules was obtained from ovules without cold pre-treatment.

II-1-4- Effect of cultivars, cold pre-treatment and media on squash ovule culture and plantlets regeneration:

Data presented in Table 4 show that the differences among treatments were highly significant for all three parameters. The highest number of plantlets per 100 cultured ovules was obtained from Rosina cv. ovules without cold pre-treatment and cultured on MS medium supplemented with $1.0 \mathrm{mg} / \mathrm{l} 2,4-\mathrm{D}$ and $1.0 \mathrm{mg} / \mathrm{l} \mathrm{Kin} \mathrm{(22.500).} \mathrm{While} \mathrm{the} \mathrm{lowest} \mathrm{number} \mathrm{of} \mathrm{plantlets}$ per 100 cultured ovules was obtained from Eskandarani cv. ovules treated for 8 and 16 days cold pre-treatment on MS medium supplemented with 5.0 $\mathrm{mg} / \mathrm{l} 2,4-\mathrm{D}(0.00)$, and from Gabbla cv. ovules at 16 days cold pre-treatment and cultured on MS medium supplemented with $1.0 \mathrm{mg} / \mathrm{l} 2,4-\mathrm{D}$ and $1.0 \mathrm{mg} / \mathrm{l}$ Kin (0.00).

The highest number of unresponded ovules per 100 cultured ovules was from 16 days cold pre-treatment of Rosina Cv. ovules cultured on MS medium supplemented with $5.0 \mathrm{mg} / \mathrm{l} 2,4-\mathrm{D}$ (92.00), while the lowest one was from Eskandarani cv. ovules which were exposed for 8 days cold pretreatment and cultured on MS medium supplemented with $5.0 \mathrm{mg} / \mathrm{l}$ 2,4-D (10.00). Data in Table 4 show that the highest number of ovules that turned to 
callus per 100 cultured ovules was obtained from Eskandarani cv. ovules which were treated for 8 days cold pre-treatment and cultured on MS medium supplemented with $5.0 \mathrm{mg} / \mathrm{l}$ 2,4-D (90.00). On the other hand, the lowest one was obtained from Rosina cv. ovules which was treated for 16 days cold pretreatment and cultured on MS medium supplemented with $5.0 \mathrm{mg} / \mathrm{l} 2,4-\mathrm{D}$ (7.00)

Table 4: Effect of cultivar, temperature pre-treatment and media on ovule culture and plantlets regeneration from squash plants.

\begin{tabular}{|c|c|c|c|c|c|c|}
\hline \multirow{3}{*}{ Cultivar } & \multicolumn{3}{|c|}{ Treatment } & \multirow{3}{*}{$\begin{array}{c}\text { No. of direct } \\
\text { plantlets / } 100 \\
\text { ovule }\end{array}$} & \multirow{3}{*}{$\begin{array}{c}\text { No. of } \\
\text { unresponsed } \\
\text { ovule / } 100 \text { ovule }\end{array}$} & \multirow{3}{*}{$\begin{array}{l}\text { No. of } \\
\text { ovules turn } \\
\text { to callus } \\
/ 100 \text { ovule }\end{array}$} \\
\hline & \multirow[t]{2}{*}{ Cold(day) } & \multicolumn{2}{|c|}{ Medium mg/l } & & & \\
\hline & & 2,4-D & Kin & & & \\
\hline \multirow{6}{*}{ Gabbla } & \multirow[b]{2}{*}{0} & 5.0 & 0.0 & $1, \mathbf{v} \cdot \mathbf{h i}$ & $r r, 0 \ldots k$ & $v 1, v 0 \cdot \mathbf{b}$ \\
\hline & & 1.0 & 1.0 & $\leq, 0 \cdots \mathrm{g}$ & $r r, 0 \ldots i j$ & $11, \vee 0 \cdot d$ \\
\hline & \multirow[b]{2}{*}{8} & 5.0 & 0.0 & $0, \ldots g$ & $r_{0,0} \cdot h_{i}$ & $\bullet १, \bullet \ldots$ de \\
\hline & & 1.0 & 1.0 & $1 r, 0 \ldots b$ & $11, \ldots \mathbf{n}$ & $v r, 0 \ldots b$ \\
\hline & \multirow{2}{*}{16} & 5.0 & 0.0 & $q, \ldots c$ & $\leq \wedge, \bullet \ldots d$ & $\varepsilon r, 0 \ldots h$ \\
\hline & & 1.0 & 1.0 & $\cdot, \ldots \mathbf{j}$ & $v r, \ldots b$ & $r v, \ldots i$ \\
\hline \multirow{6}{*}{ Eskandarani } & \multirow{2}{*}{0} & 5.0 & 0.0 & l,vo. hi & $\varepsilon \cdot, \vee \bullet \cdot$ ef & $\Delta \vee, \bullet \ldots$ efg \\
\hline & & 1.0 & 1.0 & $7.000 \mathrm{de}$ & $r \wedge, 0 \ldots \mathbf{f g}$ & $0 \leq, 0 \ldots g$ \\
\hline & \multirow{2}{*}{8} & 5.0 & 0.0 & $0.000 \mathrm{j}$ & $1 \cdots, \ldots$ & $9, \ldots a$ \\
\hline & & 1.0 & 1.0 & $2.500 \mathrm{~h}$ & m, vo. j & $70,10 \cdot C$ \\
\hline & \multirow{2}{*}{16} & 5.0 & 0.0 & $0.000 \mathrm{j}$ & $\leq 1,0 \ldots \mathrm{e}$ & $\bullet \wedge, \bullet \ldots$ def \\
\hline & & 1.0 & 1.0 & $2.500 \mathrm{~h}$ & $r_{\uparrow}, 0 \ldots \mathbf{g h}$ & $7, \mathrm{v} 0, \mathrm{de}$ \\
\hline \multirow{6}{*}{ Rosina F1 } & \multirow{2}{*}{0} & 5.0 & 0.0 & $6.000 \mathrm{f}$ & $r \wedge, \vee \bullet \cdot f g$ & $\Delta \bullet, r \bullet, \mathbf{f g}$ \\
\hline & & 1.0 & 1.0 & 22.500 a & $1 \wedge, 0 \ldots \mathbf{m}$ & $\bullet ৭, \ldots$ def \\
\hline & \multirow{2}{*}{8} & 5.0 & 0.0 & $1.000 \mathrm{i}$ & Ү , Y०, C & $r_{\cdot}, \ldots i$ \\
\hline & & 1.0 & 1.0 & $\neg, Y \bullet \cdot$ ef & $r_{1}, \ldots, I$ & VY,Vo, b \\
\hline & \multirow{2}{*}{16} & 5.0 & 0.0 & $1.000 \mathrm{i}$ & $q r, \ldots a$ & $v, \ldots j$ \\
\hline & & 1.0 & 1.0 & $7.500 \mathrm{~d}$ & $r_{0,0} \ldots$ hi & $\Delta \vee, \ldots$ efg \\
\hline & F. test & & & $\star \star$ & ** & ** \\
\hline
\end{tabular}

** Indicate highly significant differences at $\mathbf{p}<0.01$ according to $\mathrm{F}$ test .

Means followed by a common letter are not significantly different at the $5 \%$ level according to Duncan 's test

\section{II-2- Second experiment:}

This experiment was carried out to study the effect of the heat $\left(35^{\circ} \mathrm{C}\right)$ and cold $\left(4^{\circ} \mathrm{C}\right)$ shocks on ovules culture and plantlets regeneration as post-treatment on two different media by using Eskandarani cv.

II-2-1-Effect of thermal shocks (cold post-treatment $4^{\circ} \mathrm{C}$, and heat post-treatment $\left.35^{\circ} \mathrm{C}\right)$ :

Many factors are responsible for ovule culture; temperature shocks are believed to improve gynogenesis by diverting normal gametophytic development into a sporophytic pathway leading to the formation of haploid embryos. Data in Table 5 show that the highest number of plantlets per 100 cultured ovules (6.313) was obtained from ovules which were exposed to heat shock $\left(35^{\circ} \mathrm{C}\right)$ after culture. While the lowest one (3.438) was obtained from ovules which were exposed to a cold shock $\left(4^{\circ} \mathrm{C}\right)$, and the differences were highly significant. On the other hand, cold post-treatment gave the highest number of unresponded ovules per 100 cultured ovules (37.219), while the heat post-treatment gave the lowest number of 
unresponded ovules (12.750). Also, highly significant differences occurred between heat and cold post-treatment for the number of ovules that turned to callus per 100 cultured ovules. High temperature gave the highest number (80.938), while low temperature gave the lowest number (59.344).

The embryo induction experiment demonstrated that heat treatment at $35^{\circ} \mathrm{C}$ (Table 5) during the induction phase increased haploid embryos formation and plantlets regeneration. Similar results have been reported by Gemes-Juhasz et al. (2002) in cucumber, Hanna (1994) also found, in onion, that exposing ovules to $4^{\circ} \mathrm{C}$ for 4 days were the best pre-treatment and yielded highest number of plantlets.

Table 5: Effect of temperature pre-treatment on ovule culture and plantlets regeneration from squash plants (Eskandarani cv.).

\begin{tabular}{|c|c|c|c|}
\hline Pre-treatment & $\begin{array}{c}\text { No. of direct } \\
\text { plantlets / 100 ovule }\end{array}$ & $\begin{array}{c}\text { No. of unresponsed } \\
\text { ovules / 100 ovule }\end{array}$ & $\begin{array}{c}\text { No. of ovules turn } \\
\text { to callus/100 ovule }\end{array}$ \\
\hline Low temperature & $3.438 \mathrm{~b}$ & $37.219 \mathrm{a}$ & $59.344 \mathrm{~b}$ \\
\hline High temperature & $6.313 \mathrm{a}$ & $12.750 \mathrm{~b}$ & $80.938 \mathrm{a}$ \\
\hline F.test & ${ }^{\star *}$ & ${ }^{\star *}$ & ${ }^{\star *}$ \\
\hline
\end{tabular}

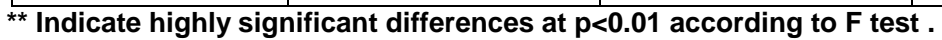

Means followed by a common letter are not significantly different at the $5 \%$ level according to Duncan 's test

II-2-2-Effect of heat and cold post-treatment and media components interaction on Eskandarani cv. ovule culture:

Data in Table 6 show the responsiveness of ovules culture to thermal shock at $35^{\circ} \mathrm{C}$ and chilling at $4^{\circ} \mathrm{C}$ for different lengths of time $(0,4,8$ and 16 days). The effect of thermal shock and chilling treatments on the number of plantlets per 100 cultured ovules was highly significant. The highest number of plantlets (17.250) was obtained from ovules treated with a treatment 8 days at $4^{\circ} \mathrm{C}$, which was cultured on MS medium supplemented with $1.0 \mathrm{mg} / \mathrm{l}$ 2,4-D and $1.0 \mathrm{mg} / \mathrm{l} \mathrm{Kin}$, and from ovules treated with a treatment of 16 days at $35^{\circ} \mathrm{C}$ which was cultured on MS medium supplemented with $5.0 \mathrm{mg} / \mathrm{l} 2,4-\mathrm{D}$ (17.00). While no plantlets were obtained from untreated ovules (control) on MS medium supplemented with $1.0 \mathrm{mg} / \mathrm{l} 2,4-\mathrm{D}$ and $1.0 \mathrm{mg} / \mathrm{l} \mathrm{Kin}$ and with treatment of 4 days at $4 \stackrel{\circ}{ } \mathrm{C}$ on both media, and with treatment of 16 days at $4{ }^{\circ} \mathrm{C}$ on MS medium supplemented with $1.0 \mathrm{mg} / \mathrm{l} 2,4-\mathrm{D}$ and $1.0 \mathrm{mg} / \mathrm{l} \mathrm{Kin}$. Also, with treatment of 4 days at $35^{\circ} \mathrm{C}$ on MS medium supplemented with $5.0 \mathrm{mg} / \mathrm{l} 2,4-\mathrm{D}$.

Data presented in Table 6 also show that the highest number of unresponsed ovules per 100 cultured ovule (83.750) was obtained from ovules treated for 16 days at $4^{\circ} \mathrm{C}$ and cultured on MS medium supplemented with $1.0 \mathrm{mg} / \mathrm{l} 2,4-\mathrm{D}$ and $1.0 \mathrm{mg} / \mathrm{K} \mathrm{Kin}$. While all ovules cultured for 4 days at $35^{\circ} \mathrm{C}$ treatment on MS medium supplemented with $5.0 \mathrm{mg} / \mathrm{l} 2,4-\mathrm{D}$ turned to embryogenic callus(100). In contrast, the lowest number of ovules that turned to callus per 100 cultured ovules (16.250) was obtained from ovules treated with $4^{\circ} \mathrm{C}$ for 16 days and cultured on MS medium supplemented with $1.0 \mathrm{mg} / \mathrm{l}$ 2,4-D and $1.0 \mathrm{mg} / \mathrm{l} \mathrm{Kin}$. 
Table 6: Effect of temperature pre-treatment and media interaction on ovule culture and plantlets regeneration from squash plants (Eskandarani cv.).

\begin{tabular}{|c|c|c|c|c|c|c|}
\hline \multirow[b]{2}{*}{ Post-treatment } & \multicolumn{3}{|c|}{ Treatment } & \multirow{2}{*}{$\begin{array}{l}\text { No. of direct } \\
\text { plantlets / } \\
100 \text { ovule }\end{array}$} & \multirow{2}{*}{$\begin{array}{c}\text { No. of } \\
\text { unresponsed } \\
\text { ovule / } 100 \text { ovules }\end{array}$} & \multirow{2}{*}{$\begin{array}{l}\text { No. of } \\
\text { ovules turn } \\
\text { to callus } \\
/ 100 \text { ovule }\end{array}$} \\
\hline & & $\begin{array}{l}\text { Mediu } \\
\text {-D }\end{array}$ & $\underset{\mathrm{Kin}}{\mathrm{mg} / \mathrm{l}}$ & & & \\
\hline \multirow{8}{*}{ Low temperature(4우) } & \multirow{2}{*}{0} & 5.0 & 0.0 & $1, v 0 \cdot e$ & $\varepsilon \cdot, v \bullet \cdot C$ & $\bullet v, \bullet \cdot g$ \\
\hline & & 1.0 & 1.0 & $\cdot, \cdots f$ & $r_{0}, \ldots e$ & $v \bullet, \ldots f$ \\
\hline & \multirow{2}{*}{4} & 5.0 & 0.0 & $\cdot, \cdots f$ & $\bullet, v \bullet \cdot h$ & $a \leq, Y 0 \cdot b$ \\
\hline & & 1.0 & 1.0 & $\cdot, \cdots f$ & $\Delta \wedge, \cdots b$ & $\varepsilon r, \cdots h$ \\
\hline & \multirow{2}{*}{8} & 5.0 & 0.0 & $v, \cdots d$ & $r \wedge, 0 \cdots d$ & $0 \leq, 0 \cdots \mathrm{g}$ \\
\hline & & 1.0 & 1.0 & $i v, r \bullet \cdot a$ & $r q, r o \cdot e$ & $04,0 \cdots \mathbf{g}$ \\
\hline & \multirow{2}{*}{16} & 5.0 & 0.0 & $1,0 \ldots e$ & $19, \vee 0 \cdot f$ & $\vee \wedge, \vee \bullet \cdot e$ \\
\hline & & 1.0 & 1.0 & $\cdot, \cdots f$ & $\wedge r, v \bullet \cdot a$ & $17, Y 0 \cdot i$ \\
\hline \multirow{8}{*}{ High temperature $\left(35^{\circ} \mathrm{C}\right)$} & \multirow{2}{*}{0} & 5.0 & 0.0 & $1, v 0 \cdot e$ & $\varepsilon \cdot, V \bullet \cdot C$ & $\Delta \vee, 0, \cdot g$ \\
\hline & & 1.0 & 1.0 & $\cdot, \ldots f$ & $r, v \bullet \cdot i$ & $94, Y 0 \cdot b$ \\
\hline & \multirow{2}{*}{4} & 5.0 & 0.0 & $\cdot, \cdots f$ & $\cdot, \cdots \mathbf{j}$ & $1 \cdots, \cdots a$ \\
\hline & & 1.0 & 1.0 & $\cdot, \bullet, f$ & $11, r 0 \cdot g$ & $\wedge \Lambda, \diamond^{\circ} \cdot \mathbf{C}$ \\
\hline & \multirow{2}{*}{8} & 5.0 & 0.0 & $v, \cdots d$ & $r \wedge, 0 \ldots d$ & $0 \leqslant, 0 \cdots \mathrm{g}$ \\
\hline & & 1.0 & 1.0 & $1 \leq, r o \cdot b$ & $\varepsilon, \cdots h \mathbf{h}$ & $\wedge 1, \vee \bullet \cdot d e$ \\
\hline & \multirow{2}{*}{16} & 5.0 & 0.0 & $i v, \cdots a$ & $\cdot, 0 \ldots j$ & $\wedge r, \diamond \cdots d$ \\
\hline & & 1.0 & 1.0 & $1 \cdot, \cdots c$ & $r, r o \cdot \mathbf{i}$ & $\wedge \neg, \vee \bullet \cdot C$ \\
\hline F. test & & & & $\star *$ & $\star \star \star$ & ** \\
\hline
\end{tabular}

** Indicate highly significant differences at $\mathrm{p}<0.01$ according to $\mathrm{F}$ test .

Means followed by a common letter are not significantly different at the $5 \%$ level according to Duncan's test.

\section{III - Cytological Studies:}

Root-tips from 20 androgenic and gynogenic plants from each genotype were cytologically examined under a light microscope. Plants derived from ovule culture, are classified to $64 \%$ haploids $(2 n=x=20)$ and (36) \% were diploid $(2 n=2 x=40)$ in Rosina $F_{1}$, and were $58 \%$ haploid and $42 \%$ were diploid in Gabbla cv. , and were $41 \%$ haploid and $59 \%$ were diploid in Eskandarani cv.( Fig. 8 ).

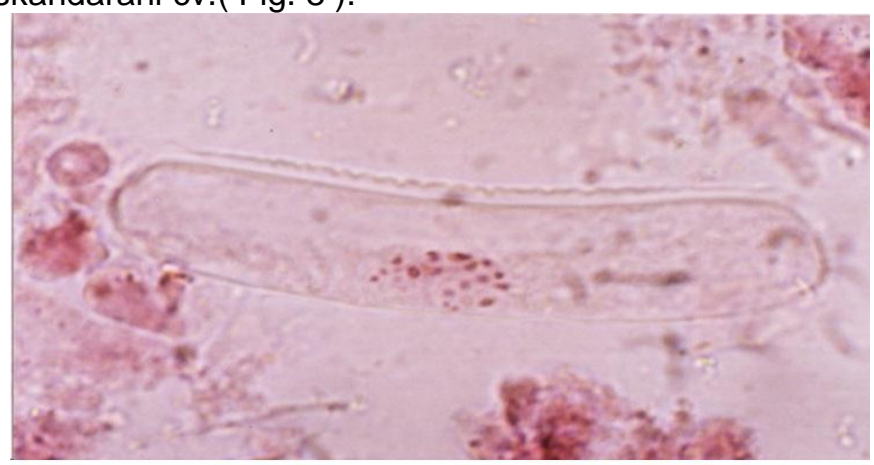

Fig. 8. Mitotic metaphase of haploid plants $(2 n=x=20)$

In conclusion using the improved ovule culture methods allow efficient haploid-plants and doubled haploid lines in squash in order to develop new varieties. 


\section{REFERENCES}

Gemes-Juhasz, A.; P. Balogh and A. Ferenczy. 2002 . Effect of optimal stage of female gametophyte and heat treatment on in vitro gynogenesis induction in cucumber (Cucumis sativa L.). Plant Cell Rep., 21:105111.

Hanna, A.B.1994. Genetic evaluation of some economic characters in onion (Allium cepa ). Ph. D. Thesis, Fac. Of Agric. Moshtohor, Zagazig Univ. Banha Branch.

Kwack, S. and N. Fujieda .1988. Somatic embryogenesis in cultured unfertilized ovules of Cucurbita moschata. J. Japanese Hort. Sci., 57(1):34-42.

Lux, H.; L. Herrmann. and C. Wetzel. 1990. Production of haploid sugar beet (Beta vulgaris L.) by culturing unpollinated ovules. Plant Breed., 104: 177-183.

Metwally ,E.; S. A. Mostafa; B. J. El-Sawy and T. A. Shalaby .1998. Production of haploid plants from in vitro culture of unpollinated ovules of Cucurbita pepo L. Plant Cell,Tissue and Organ Culture, 52:117-121.

Pallares, P. 1984. First results from in vitro culture of unfertilized cotton ovules (Gossypium hirsutum ). Coton et Fiberes Tropicales, 39(4):145152.

Shail, J.W. and R.W. Robinson. 1987. Anther and ovule culture of cucurbita. Cucurbit. Genet. Cooperative., 10:92.

Vaulx, D. D. and D. Chambonnet. 1986. Obtaination of embryos and plants from in vitro culture of unfertilized ovules of Cucurbita pepo. Genetic Manipulation in Plant Breed., 295-297.

\footnotetext{
الاتتاج المكثف للنباتات الاحادية المتضاعفة من قرع الكوسة عن طريق زراعة البويضات

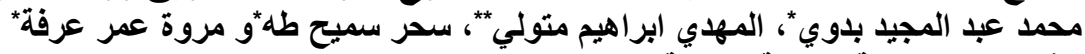

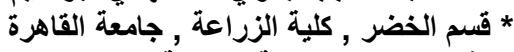
** قسم البساتين , كلية الزراعة, كفر الثيخ , جامعة طنطا

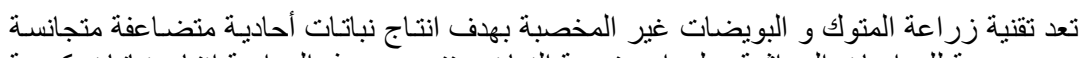

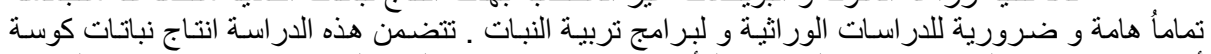

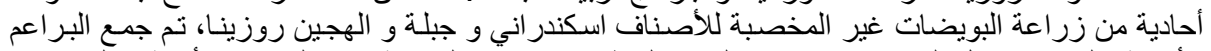

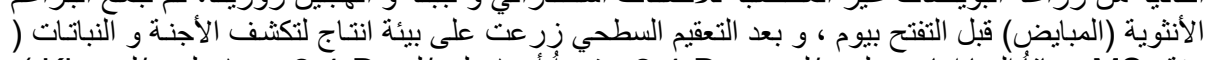

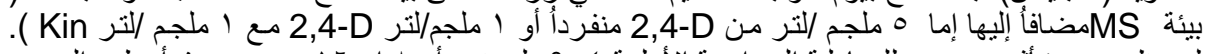

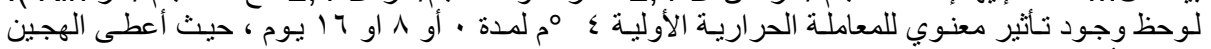

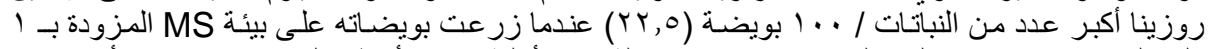

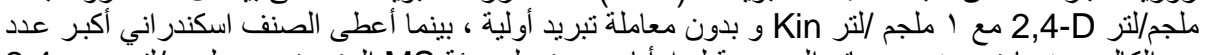

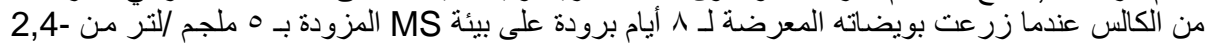

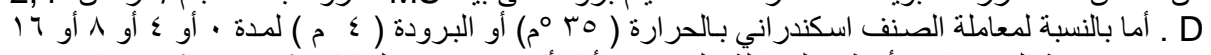

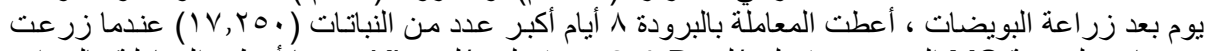

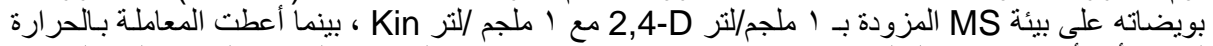

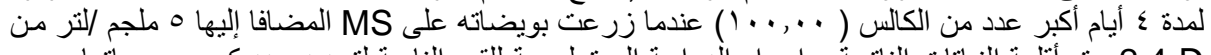
2,4-D ـ تم أقلمة النباتات الناتجة و إجراء الدراسة السيتولوجية للقمم النامية لتحديد عدد كروموسوماتها .
} 